\section{PROVIDING A WATER DELIVERY SERVICE THROUGH DESIGN \\ MANAGEMENT INTERACTIONS AND SYSTEM MANAGEMENT}

Achieving control for water pricing

B.A. LANKFORD

School of Development Studies, University of East Anglia, Norwich, UK

J. GOWING

Centre for Land Use and Water Resources Research, University of Newcastle upon Tyne, UK

\section{Abstract}

The premise that water for irrigation should be treated as an economic good, in the same way as other agronomic inputs, holds only if its supply is controllable. The design and management capability of an irrigation system to provide control over water is therefore critical. Three main types of potential water supply control can be identified based on increasing accuracy of allocation under higher standards of performance. The three types, which arise via design management interactions, are water provision, water distribution and water partition. Water control can improve within each type or it can move from one to another by engaging in design management interactions. It is the water distribution and water partition levels which enable higher service standards and a realistic means to charge for water used. Recognition of these concepts is important both to diagnosis of on-going management problems and to the design of new and rehabilitated systems.

Keywords: Canal irrigation, control, delivery, design, management, pricing.

\section{Introduction}

Much current interest in irrigation management relates to the broader issues of the changing role of the state in natural resource management. The motivating force is the belief that users of natural resources should be responsible for their management to a much greater extent. Accompanying this shift of responsibility is a desire to introduce "market forces" in order to promote increased efficiency.

Irrigation management transfer embraces a range of initiatives aimed at devolving

1. Lankford, B. A. and Gowing, J. (1997). Providing a water delivery service through design management interactions and system management, in Water: Economics, Management and Demand, (eds M. Kay, Franks, T. and Smith, L.) E \& FN Spon, London, pp 238-246.
O\&M responsibility to users. There is an underlying assumption that farmer managed irrigation schemes (FMIS) are more efficient than those run by public officials and are more responsive to the needs of their users. However evidence for this is insubstantial and further attention needs to be given to efficiency and equity assessments [1]. Much of the research into FMIS has concentrated on small-scale traditional schemes and mption that lessons from effectively to large scale public systems. This assumption is flawed [2] and there is growing recognition of the importance of technology/management interactions [1]

It is argued that the costs of irrigation service provision should be borne by the beneficiaries and there is an extensive literature on cost-recovery strategies [3]. But as Bottrall (quoted in [4]) points out; "despite the desirability of raising water charges, it should be seen as a secondary issue in terms of sequential actions, first because it is a highly politicised issue; and secondly because in most cases farmers will not become better disposed to the idea of higher charges unless other changes are made first - the most important of which is an improved water distribution service."

Analysts point to the dominance of irrigation demand in the face of increasingly scarce water resources and advocate market-based allocation based on an assessment of the economic value of water. It follows that in order to ration water use by price, direct volumetric measurement of demand is inescapable. This has significant technological implications in that the means of making such measurements seldom exists on large-scale public canal systems. The limitations of efficiency gains from introduction of market forces should therefore also be seen in relation to technology management interactions. This paper deals with the issue of the standard of delivery service in large irrigation schemes based upon gravity (i.e. canal) distribution. The importance of control over supply to users is emphasised and the dependence on engineering is discussed in the context of design management interactions.

\section{Definitions of design management interactions}

Design management interactions have been analysed at different levels which are described below in order of an increasing appreciation of their complexity:

1. System-technology: The 3 main irrigation technologies; gravity (canal), sprinkler and drip (trickle), each have specific management requirements. This paper is concerned with design management interactions on gravity irrigation systems.

2. Size of scheme: Researchers have identified links between scheme size, complexity and water control [5], with very large and large schemes, typically 1000 to 10,000 ha and over requiring "full water control"; medium-scale schemes, 100 to 1000 ha, needing "full or partial water control" and small scale schemes, 1 to 100 ha, being controlled by farmer groups or single farmers.

3. Structure-use: Researchers have investigated the difficulty or "user-friendliness" and degree of manual or automatic operation of structures for water control. These address control of either water levels or discharges or both using single structures or combinations. A good example of this type of analysis is found in Plusquellec et al [4] who discuss use-related interactions under 'Robustness' and 'Ease of Operation', and include a subsection entitled 'Specific structures to avoid.' 
4. Management-aim: Closely related to the previous analysis, is the discussion of design in the light of how it assists with a water management aim, the common one being to measure water flow. For example: "Usually water measurements should be planned at all points where it can be reasonably established that information on the flow rate will affect management decisions" [6]. Furthermore, "the flexibility to cope with given situations rests largely upon the cost and type of regulation structures and techniques used in the canal network" [7]. Plusquellec et al [4] examine management aims under 'Functionality of control structures', where they identify the need for sufficient structures to ensure adequate water-level control, via such functions as on-off and flow rate adjustment. The problem with focusing only on use-related and management-related interactions is that while these are critical to water control, they exclude many other factors which enable irrigation schemes to have enhanced self-running capabilities under conditions of required higher performance. For this it is necessary to look at wider design management interactions that explicitly affect performance.

5. Implicit performance-affecting interactions: Prior to discussing the explicit performance-affecting interactions, it is useful to examine how design and management are implicitly presented as factors influencing performance. For example Uphoff et al [8] describe a 3 dimensional matrix of irrigation management arising from 'water delivered to the crops' (made up from acquisition, allocation, distribution and drainage), 'control structures activities' (design, construction, operation and maintenance) and 'organisational activities' (decision making, resource mobilisation, communication and conflict management). While on the face of it, this matrix hints at interactions, the text does not explain how and fails to address the design-side at all: "Because this study focuses on improving the management of existing systems, we concern ourselves only with the latter. Happily, this reduces the number of management variables to be considered." It is this the lack of focus on interactions with design that hinders management from investigating new designs to observe how they improve allocation and performance.

6. Explicit performance-affecting interactions: Researchers are beginning to believe that explicit system-wide design management interactions influence performance. Dargouth [9] highlights the interdependence of system design and water management but acknowledges that research on the subject has been carried out by a few. Ankum [10] states; "flow control systems have developed through a gradual evolution from simple towards high technology, keeping pace with the increasing performance requirements." Bos and Nugteren [11] describe conditions that favour the efficient use of irrigation water and second in the list is the control over water flow to the system and within it: "Only then will it be possible to establish a close match between crop irrigation water requirements and water supply." Turral [1] notes that experience of successful management transfer from USA, Japan, Taiwan and Korea may be misleading in that the physical infrastructure was functioning well and in some cases was improved as a precondition for transfer: "In contrast, many systems in developing countries may suffer from inherent design or construction problems." The remainder of the paper develops the concepts behind these system-wide design management interactions which characterise and affect the delivery of water on irrigation systems.

\section{System-wide design management interactions}

Design management interactions give rise to three main types of irrigation systems termed water provision, water distribution and water partition. Table 1 presents the 3 types and their main characterising features, which arise from management and engineering choices regarding system infrastructure design, system configuration design and design operational procedures. Further details and discussion on the method of characterisation of irrigation systems is found elsewhere [12]. New and different names are suggested for the main/secondary canals and tertiary canal/field delivery systems. For example, water partition systems consist of division canals supplying water to apportionment canals.

\begin{tabular}{ccc} 
Table 1. Diagnostic features of three main types of design management interactions \\
\hline Design $\quad$ Main and $\quad$ Secondary canal Distinguishing/diagnostic feat
\end{tabular}

$\begin{array}{llll}\begin{array}{l}\text { Design } \\ \text { management }\end{array} & \begin{array}{l}\text { Main and } \\ \text { secondary }\end{array} & \begin{array}{l}\text { Secondary canal } \\ \text { to tertiary/field }\end{array} & \text { Distinguishing/diagnostic features } \\ \text { type } & & \end{array}$

management secondary to tertiary/fiel

Water Transfer Dispersal • Lack of flow measurement

provision network network $\quad$ Variety of canal system operational schedules

- Discharge control mainly at headworks

- No or rare head/level control

- Simple sluice gates with on off capability

Or proportional distributors off capability

- Or single flow is rotated

- Reservoir or canal night storage is rare

\begin{tabular}{|c|c|c|c|}
\hline $\begin{array}{l}\text { Water } \\
\text { distribution }\end{array}$ & $\begin{array}{l}\text { Conveyance } \\
\text { network }\end{array}$ & $\begin{array}{l}\text { Distribution } \\
\text { network }\end{array}$ & $\begin{array}{l}\text { - Emphasis on controlling water levels }(\mathrm{cm}, \mathrm{m}) \\
\text { - Variety of canal system operational schedules }\end{array}$ \\
\hline $\begin{array}{l}\text { Sub-type: } \\
\text { Level } \\
\text { control }\end{array}$ & & & $\begin{array}{l}\text { - Steady or non steady water level control } \\
\text { - Manual-active to automatic level adjustment } \\
\text { - Continuous water level adjustment } \\
\text { - Flow measurement is rare } \\
\text { - } \text { Oarious types of rotation } \\
\end{array}$ \\
\hline $\begin{array}{l}\text { Sub-type: } \\
\text { Discharge } \\
\text { control }\end{array}$ & & & $\begin{array}{l}\text { - Emphasis on controlling flow rates }(1 / \mathrm{sec}) \\
\text { - Variety of canal system operational schedules } \\
\text { - Manual-active/passive flow measurement } \\
\text { - Variable/active head control structures } \\
\text { - Manual-active to automatic adjustment } \\
\text { - Occasional reservoir or canal night storage }\end{array}$ \\
\hline $\begin{array}{l}\text { Water } \\
\text { partition }\end{array}$ & $\begin{array}{l}\text { Division } \\
\text { network }\end{array}$ & $\begin{array}{l}\text { Apportionment } \\
\text { network }\end{array}$ & $\begin{array}{l}\text { - Emphasis on controlling supply hydromodules } \\
\text { to match with demand hydromodule (1/sec/ha) } \\
\text { - Structured system of canal scheduling } \\
\text { - Adjustable headwork discharge control } \\
\text { - Automatic/passive water measurement and } \\
\text { - head control } \\
\text { - Stepped/fixed/passive flow adjustment } \\
\text { - Matching command areas } \\
\text { - } \text { Conilt-in design for strict rotation of water } \\
\text { - Possible night storage via reservoir or canal }\end{array}$ \\
\hline
\end{tabular}




\subsection{Water provision systems}

The key feature of water provision systems is the absence of water flow measurement. Water level and discharge control are sufficient to minimise over-spills. Good examples of such systems are small-scale farmer operated schemes and some warabundi-based schemes at the larger scale.

\subsection{Water distribution systems}

These are the most common type of larger scale irrigation systems. Regarding their main distinguishing features, two sub-types exist either with an emphasis on discharge $(1 / \mathrm{sec})$ control or water level control. The kinds of technologies found on these schemes is wide-ranging from intensive manual methods to automatic control.

\subsection{Water partition system}

These systems are the rarest, with an emphasis on the accurate, strict control of the ratio of water supply to area (litres/second/hectare) which is termed the supply hydromodule. On such systems, water is seen as a scarce resource and is measured and managed in fractions of $1 / \mathrm{sec} / \mathrm{ha}$, and is carefully matched with crop and system water demands, termed the demand hydromodule. These systems differ from distribution systems in that water supply control is reliant on a multi-factor, systems approach which includes the use of 'structured' canal scheduling [13], accurate design sizing, carefully chosen gate and water level control technologies, strict rotation patterns, good infield design and a matching of main to tertiary canal operation and design. During peak demand periods, flexibility of allocation is reduced to increase the frequency of cycling of water between fields. At present, only a few examples of such systems - in drought-prone areas in Southern Africa - are known to the authors.

\section{System management}

The above design management interactions do not solely define the standard of water allocation. There is the possibility of improvement of water management within each of the design management types, and this gives a further dimension to the analysis. Two broad management types have been identified, termed 'normal' and 'actualising'.

\subsection{Normal management}

This term is borrowed from Chambers' [14] analysis of "normal" irrigation professionalism. In such systems, the system is operated with much visible daily activity, but with little progression in long-term performance. Brief examples of activities associated with normal management are outlined in Table 2.

\subsection{Actualising management}

This term implies the set of skills required to improve system management which results in consistent long-term enhanced performance. Described by Chambers under the banner "new" professionalism, some examples of these skills are provided in Table 2 under two main activities; diagnostic analysis and practical action. Both go hand in hand in iterative circles encouraging managers to learn how to improve performance.

\begin{tabular}{llll}
\hline & Normal & \multicolumn{2}{c}{ Actualising } \\
& & Diagnostic analysis & Practical action \\
\hline $\begin{array}{l}\text { Infrastructure and in- } \\
\text { field design }\end{array}$ & Accepts design & Questions design & $\begin{array}{l}\text { Introduces trials and } \\
\text { new designs, layouts, } \\
\text { methods, etc. }\end{array}$ \\
\hline $\begin{array}{l}\text { Main system } \\
\text { management }\end{array}$ & $\begin{array}{l}\text { Accepts current methods } \\
\text { or operates incorrectly }\end{array}$ & $\begin{array}{l}\text { Examines effects on } \\
\text { allocation }\end{array}$ & $\begin{array}{l}\text { Alters methods and } \\
\text { diagnoses new impacts }\end{array}$ \\
\hline $\begin{array}{l}\text { Monitoring and } \\
\text { evaluation }\end{array}$ & Omitted or by rote & $\begin{array}{l}\text { Investigates need and } \\
\text { methods of data } \\
\text { collection and } \\
\text { analysis }\end{array}$ & $\begin{array}{l}\text { Regular summaries and } \\
\text { feedback into } \\
\text { management. Active } \\
\text { use of computers }\end{array}$ \\
\hline $\begin{array}{l}\text { Leaks/spills/ } \\
\text { equipment and canal } \\
\text { maintenance }\end{array}$ & Omitted or by rote & $\begin{array}{l}\text { Determines level of } \\
\text { cost-effectiveness }\end{array}$ & $\begin{array}{l}\text { Flexible approach. } \\
\text { Tries different methods } \\
\text { \& equipment }\end{array}$ \\
\hline $\begin{array}{l}\text { Interdisciplinary } \\
\text { interaction }\end{array}$ & $\begin{array}{l}\text { Isolated, does not seek } \\
\text { interaction with others }\end{array}$ & $\begin{array}{l}\text { Questions source \& } \\
\text { level of own } \\
\text { knowledge }\end{array}$ & $\begin{array}{l}\text { Seeks out and works } \\
\text { with other specialists }\end{array}$ \\
\hline $\begin{array}{l}\text { Management \& } \\
\text { technical skills }\end{array}$ & Possibly too narrow & Questions own skills & $\begin{array}{l}\text { Seeks new training \& } \\
\text { motivation }\end{array}$ \\
\hline $\begin{array}{l}\text { People/farmer } \\
\text { management \& } \\
\text { management transfer }\end{array}$ & $\begin{array}{l}\text { Exclusive, conflict- } \\
\text { orientated, partial } \\
\text { transference }\end{array}$ & $\begin{array}{l}\text { Diagnoses situation, } \\
\text { need, abilities, } \\
\text { opportunities }\end{array}$ & $\begin{array}{l}\text { Flexible, participatory, } \\
\text { conflict-resolving, } \\
\text { communicative }\end{array}$ \\
\hline
\end{tabular}

\section{Framework of water supply control}

The two dimensions of design management interactions and system management provides a $3 \times 2$ framework of water supply control. This framework of 6 classes is presented in Table 3 along with some water delivery symptoms that might be found within each class. Also included in Table 3 is the proposal that the three levels of design management interactions have associated means of charging users for water. Charging accurately for water on a volumetric basis might be better suited to partition systems where either the time of delivery converts directly to volume applied or, because of the degree of control, even simply counting the number of irrigations gives the amount of water used. Volumetric charging on distribution systems is possible but imposes a greater burden of measurement of flows. Alternatively, fixed and nonvolumetric direct charges may be more appropriate on distribution and water provision systems. Moreover, a dependable fair delivery service, necessary for successful collection of water payments, can only occur when irrigation management is in the actualising mode, and this may apply to all three design management types.

\section{Conclusion}

If water is to be introduced as an economic good on irrigation systems, managers need to be able to treat it as such, and farmers need to have the same view based on an 


\begin{tabular}{|c|c|c|c|}
\hline & & \multicolumn{2}{|c|}{ System management dimension } \\
\hline & & Normal & Actualising \\
\hline & $\begin{array}{l}\text { Water } \\
\text { provision } \\
\text { (WPV) }\end{array}$ & $\begin{array}{l}\text { - Incorrect settings of } \\
\text { structures } \\
\text { - Leaks \& spills } \\
\text { - Excessive water abstraction } \\
\text { - Or poor irrigation } \\
\text { scheduling } \\
\text { - Unable to match delivery } \\
\text { service with water charges }\end{array}$ & $\begin{array}{l}\text { - Infield losses low } \\
\text { - Settled system with few } \\
\text { leaks/spills } \\
\text { - Scheduling or organised cycling } \\
\text { minimises over-irrigation } \\
\text { - Able to deliver and charge by } \\
\text { fixed/direct means (payment per } \\
\text { irrigation, irrigation services, } \\
\text { land \& crop taxes, water rights) }\end{array}$ \\
\hline \multirow[t]{2}{*}{$\begin{array}{l}\text { Design } \\
\text { management } \\
\text { dimension }\end{array}$} & $\begin{array}{l}\text { Water } \\
\text { distributio } \\
\mathrm{n} \\
(\text { WDB })\end{array}$ & $\begin{array}{l}\text { - Misuse of existing structures } \\
\text { leading to lack of control } \\
\text { - No measurement or } \\
\text { collection of water flow data } \\
\text { - Breakdown of water cycling } \\
\text { - Spills and leaks } \\
\text { - Unable to match delivery } \\
\text { service with water charges }\end{array}$ & $\begin{array}{l}\text { - Correct use of canal structures } \\
\text { - Water rotation followed } \\
\text { - Collection and analysis of data } \\
\text { - Computerisation of scheduling } \\
\text { and irrigation management } \\
\text { - Able to deliver and charge by } \\
\text { fixed/direct means (payment per } \\
\text { irrigation, irrigation services, } \\
\text { land \& crop taxes, water rights) }\end{array}$ \\
\hline & $\begin{array}{l}\text { Water } \\
\text { partition } \\
\text { (WPT) }\end{array}$ & $\begin{array}{l}\text { - In-field losses high } \\
\text { - } \text { Broad design } \\
\text { approximations } \\
\text { - Leaks and spills } \\
\text { - Inequalities of } \\
\text { supply/demand match } \\
\text { - Delays in irrigation } \\
\text { scheduling during peak } \\
\text { periods } \\
\text { - Unable to accurately } \\
\text { determine allocations }\end{array}$ & $\begin{array}{l}\text { - Improvement of infield- } \\
\text { irrigation methods } \\
\text { - Accurate design of } \\
\text { infrastructure } \\
\text { - Removal of canal supply } \\
\text { bottlenecks and leaks } \\
\text { - Appropriate maintenance } \\
\text { - Evaluation of equity of supply } \\
\text { - Able to deliver water to meet } \\
\text { evaporative demand and to } \\
\text { charge for water volumetrically }\end{array}$ \\
\hline
\end{tabular}

experience of improved delivery services. Both of these depend on accurate control of water. The concepts presented in this paper enable the diagnosis of control problems on irrigation schemes via a framework based on a systems nature of water supply control arising out of many design and management factors and their interactions. It is because of these complex interactions that water control in some cases has not responded to the introduction of new control technology alone and why a distribution system, which has the means to control flows but does not do so, may be similar in performance terms to a provision system which does have good water management.

However, this analysis does not necessarily call for systems to move through the levels of design management interactions from provision to partition. Each system should be evaluated on a case-by-case basis, and may be found to be appropriately designed. Most systems (for example small scale systems and those in humid areas) operate reasonably well with approximate information on volumes suggesting that exact measurements are often not necessary for adequate system management [8].

Even so, in some instances control is insufficient to allow for water to be treated as an economic commodity and this analysis suggests that the introduction of (new) market forces demands an understanding of the systems nature of water supply control on irrigation schemes. Then, for individual schemes, the questions are; what type of system is it, what type of market transaction is most appropriate, and what kinds of technical and institutional interventions are required to enhance water supply control in order to promote the success of those water charges?

Acknowledgements: B.A. Lankford gratefully acknowledges the Royal Academy of Engineering (1996 award) and Simunye Estate, (esp. Richard Orr) for their support.

\section{References}

1. Turral, H. (1995) Devolution of Management in Public Irrigation Systems: Cost shedding, empowerment and performance. ODI Working Paper 80, ODI, London.

2. Merrey, D. J. (1994) Institutional design principles for accountability on large irrigation systems, in Proc. Int. Conf. on Irrigation Management Transfer, Wuhan, China.

3. Small, L. and Carruthers, I. (1992) Farmer Financed Irrigation, Cambridge UP.

4. Underhill, H. W. (1990) Small-scale irrigation in the context of rural development. Cranfield Press, UK

5. Plusquellec, H., Burt, C. and Wolter, H. W. (1994) Modern Water Control in Irrigation. Concepts, Issues, and Applications. World Bank Technical Paper No. 246. Irrigation and Drainage Series. World Bank, Washington DC, USA.

6. Clemmens, A. J., Bos, M. G. and Replogle, J. A. (1993) FLUME: Design and calibration of long-throated measuring flumes, ILRI Publication 54, Wageningen.

7. Verdier, J. (1987) Computerised control of irrigation water distribution. ODI/IIMI Irrigation Management Network Paper 87/1d, 18 pp, ODI, London.

8. Uphoff, N., Ramamurthy, P. and Steiner, R. (1991) Managing irrigation; analysing and improving the performance of the bureaucracies, SAGE Pub., New Delhi.

9. Dargouth, M. S. (1992) Institutional Aspects of Irrigation Development in North Africa: Experience with Morocco, in Developing and Improving Irrigation and Drainage Systems (eds G. Le Moigne, S. Barghouti, and L. Garbus), World Bank Technical Paper No 178, World Bank, Washington DC.

10. Ankum, P. (1990) Classification of flow control systems for irrigation. In Int. Workshop on Design for Sustainable Farmer-Managed Irrigation Schemes in SubSaharan Africa in Zimbabwe, Agricultural University, Wageningen.

11. Bos, M. G. and Nugteren, J. (1992) On Irrigation Efficiencies. 5th Edition, International Institute for Land Reclamation and Improvement, The Netherlands.

12. Lankford, B.A. and Gowing, J. (1996) Understanding water supply control in canal irrigation systems, in Water Policy: Allocation and Management in Practice, (eds P. Howsan and R. Carter), E \& FN Spon, London, pp 186-193.

13. Shannan, L. (1992) Planning and management of irrigation systems in developing countries. Agricultural Water Management, Vol 22, pp 3-14.

14. Chambers, R. (1988) Managing Canal Irrigation. Practical analysis from South Asia, Wye Studies in Agricultural and Rural Development, Cambridge UP. 